\title{
SECURITY INTERESTS AND BANKRUPTCY PRIORITIES: A REVIEW OF CURRENT THEORIES
}

ALAN SCHWARTZ

Replaces California Institute of

Technology Social Science Working

Paper \# 334

Reprinted for private circulation from The Journal of LEGAL STUDIES

Vol 10, No. 1, January 1981

(c) 1981 by The University of Chicago PRNTED IN D.S.A. 


\title{
SECURITY INTERESTS AND BANKRUPTCY PRIORITIES: A REVIEW OF CURRENT THEORIES
}

\author{
ALAN SCHWARTZ*
}

I $\mathrm{N}$ recent years, finance economists have begun to study several practices that the law traditionally regulates. Examples include attempted explanations of the variety of debt and equity instruments that firms issue ${ }^{1}$ the nature of bond covenants, ${ }^{2}$ the functions that trade credit serves ${ }^{3}$ and the likely actions of creditors when their debtor becomes insolvent. ${ }^{4}$ These studies are illuminating and provocative, but represent only the beginning of coherent explanations of the phenomena. Also, the normative implications of this relatively incomplete understanding have been unexplored. Lawyers assume these financial practices to be well understood and, consequently, have erected regulatory structures that presuppose the truth of what now seem preliminary or questionable positivist theories. This paper explores a particular financial practice-the issuance of debt secured by personal property - and a regulatory scheme relevant to this practice-the setting of distributional priorities when an insolvent firm is liquidated. My principal purpose is to illuminate the unresolved

* Visiting Professor of Law and Social Science, California Institute of Technology; Maurice Jones, Jr. Professor of Law, University of Southern California Law Center. I would like to thank John Borgo, David Carroll, Robert Forsythe, Michael J. Graetz, Thomas H. Jackson, Anthony T. Kronman, George L. Priest, Robert E. Scott, Matthew Spitzer, James Strnad and Louis L. Wilde for very helpful suggestions. This paper also benefited substantially from comments received at the Law and Economics Workshop at the University of Chicago and the University of Southern California Faculty Workshop. Portions of this paper will appear in revised form in Alan Schwartz \& Robert E. Scott, Commercial Law: Principles and Policies (forthcoming).

${ }^{1}$ Charles W. Haley \& Lawrence D. Schall, The Theory of Financial Decisions 379-83 (2d ed. 1979).

${ }^{2}$ Clifford W. Smith \& Jerold B. Warner, On Financial Contracting: An Analysis of Bond Covenants (1979) (Working Paper \# MERC 78-04, Univ. of Rochester).

${ }^{3}$ Robert A. Schwartz \& David K. Whitcomb, The Trade Credit Decision, in Handbook of Financial Economics 257 (James L. Bicksler, ed. 1979).

${ }^{4}$ Jeremy I. Bulow \& John B. Shoven, The Bankruptcy Decision, 9 Bell J. Econ. 437 (1978). For critical comments, see James S. Ang \& Jess H. Chua, Coalitions, the Me-First Rule, and the Liquidation Decision, 11 Bell J. Econ. 355 (1980). 
problems in this field and to illustrate the relevance of the achievements and unaccomplished tasks of modern finance to areas of business law that have developed largely independently of this discipline.

If an insolvent debtor's business is liquidated, its secured creditors may take property subject to their liens before any other creditors are paid. ${ }^{5}$ Congress has also created six classes of "priority" creditors, the most important of which are expenses of administration (first priority), wage and employee-benefit claims up to limited amounts (third and fourth priority) and taxes (sixth priority). Each priority class is paid in full, to the extent available assets exist, before the next class is paid. ${ }^{6}$ Finally, "general" creditors, those without security interests or priority status, receive payment if payment is possible. As this priority list suggests, secured creditors do much better than general creditors in bankruptcy liquidations.

The principal justification for a distribution scheme that seemingly advantages the sophisticated and relatively affluent, who often take security, at the expense of the relatively poor and unsophisticated, who often do not, is that the institution of secured debt is efficient. Lawyers commonly make this claim in a slightly different form, asserting that the ability of firms to give security increases the amount of credit available to the firms, but the implicit premise is that the gains to firms and secured creditors from additional credit exceed the costs that security may occasionally impose on priority and general creditors. ${ }^{7}$ This efficiency justification has prevailed; the accepted wisdom holds that the current bankruptcy priority list is normatively desirable.

${ }^{5}$ Bankruptcy Reform Act of 1978, 11 U.S.C. 724(b)(1) (hereinafter cited without crossreference as Bankruptcy Act).

${ }^{6}$ Bankruptcy Act $\S 507$. A useful general discussion of bankruptcy distributions, though dated in detail, is James MacLachlan, Bankruptcy 145-54 (1956).

${ }^{7}$ Security could be efficient in the Pareto-superior or Kaldor-Hicks sense. To perceive the difference, suppose that a security interest reduces the risks of a secured creditor by more than it increases the risks of unsecured creditors. Consider two cases. First, all creditors are aware of the existence of security: consequently, the secured creditor charges lower interest rates than it would have charged had it not taken security, and the unsecured creditors charge higher interest rates than they would have charged if no security existed. Since in this illustration the benefits of the interest rate reduction exceed the costs of the rate increases by assumption, security is (almost) Pareto superior; the debtor and secured creditor are made better off by its existence while actual unsecured creditors are as well off as without security because they are paid to bear the increased risks that security imposes. Some risk-averse persons, however, may be discouraged from lending. Second, suppose that some unsecured creditors charge the same interest rates they would have charged had no secured debt been issued because they are too unsophisticated to react appropriately to security. In this case. secured debt makes these unsophisticated creditors worse off because their risks increase but they receive no additional compensation. Security would nevertheless be efficient in the Kaldor-Hicks sense. The gainers from security-the debtor and secured creditor-could compensate the losers - the unsophisticated creditors-and remain better off than without 
This paper reviews the accepted wisdom. Part I briefly discusses the factual context and the law of personal property security. Part II explores the efficiency justification for the Bankruptcy Act's favorable treatment of personal property secured debt. It argues that this justification is weak because efficiency explanations for why firms issue secured debt either predict wrongly when it will and when it will not be sold, fail to account for the use of security rather than other contractual devices that apparently can accomplish the same ends, or fail to show that security reduces net social costs. Part III next considers distributional explanations for the practice of firms to issue secured debt. It is shown that firms sometimes have incentives to issue secured debt to redistribute wealth from particular unsecured creditors to themselves, but that distributional explanations for the existence of secured debt are also ultimately unsatisfying. Finally, Part IV initially asks what should be done if the efficiency justification for current law is rejected. This stance implies that the most appropriate reform would be to elevate the priority status in bankruptcy liquidations of creditors thought deserving of help. Part IV, however, also shows that the normative theories relevant to the question which bankruptcy priority list is preferable are sufficiently primitive to make questionable any such case for radically altering present law.

This essay's principal conclusion, therefore, is that scholars and decision makers should no longer regard as settled the question which bankruptcy priority list is normatively preferable. Much more work must be done to make compelling the efficiency defense of current law, yet normative justifications for altering this law are also poorly developed.

\section{The factual Context and the Law}

\section{A. The Factual Context}

Firms issue debt on short and long-term bases. Short-term debt usually is payable within a year, whereas long-term debt may be outstanding for thirty or more years. Debt of two kinds is issued because firms often have cyclical financing needs. If firms issued only long-term debt to finance long-term and current needs, they would thus be paying interest for short-term financing in periods when no short-term financing was necessary. To avoid this waste, firms finance long-term needs, such as for

security, by the assumption that security reduces the risks of the secured party by more than it increases the risks of the unsecured creditors. The normative efficiency defense of the code and Bankruptcy Act would obviously be stronger if secured debt were shown to be (almost) Pareto superior to unsecured debt when security was taken. See text at notes 58-60 infra. 
capital assets or realty, with long-term debt and short-term needs, such as for inventory and raw materials, with short-term or current debt. ${ }^{8}$

To be used as collateral for long-term debt, personal property must have sufficient longevity to make a satisfactory lien possible. Much personal property fails to satisfy this requirement. Thus long-term debt is commonly secured with real estate and unusually long-lived industrial capital such as railroad-rolling stock. ${ }^{9}$ Short-term debt is usually secured with inventory, accounts receivable, equipment with a relatively short life, and negotiable instruments or instruments of credit. ${ }^{10}$ This paper's concern with security interests in personal property thus requires it to focus primarily on short-term debt. The security interests that sometimes accompany short-term debt are regulated by the Uniform Commercial Code.

\section{B. The Law,}

Although secured parties always have come first in bankruptcy liquidations, the law was traditionally believed to have struck a rough balance between the interests of secured and unsecured creditors. This was largely because security, especially personal property security, was costly to take, state law having established difficult requirements for creating and giving public notice of security interests. ${ }^{11}$ Consequently, it was inconvenient for creditors to put a lien on all of a debtor's assets; a "cushion of free assets" was sometimes available to satisfy at least a portion of the claims of those creditors thought least able to protect themselves-employees, tenants, small-trade creditors. The Uniform Commercial Code, which was adopted in the middle 1960s, upset this supposed balance. The principal object and chief success of article 9 of the code was significantly to reduce the costs accompanying the issuance

\footnotetext{
8 "Middle-term" debt, outstanding for one to five years, is sometimes secured with heavy industrial machinery. This debt seems less significant in volume than the short and longterm debt that the text discusses.

${ }^{9}$ See William H. Husband \& James C. Dockeray, Modem Corporation Finance 113-14 (7th ed. 1972).

${ }^{10}$ A good description of this financing is found in James C. Van Home, Financial Management and Policy 458-69, 476-77 (4th ed. 1977). Unsecured trade credit, however, is the largest single source of short-term corporate debt. In first quarter 1976, for example, trade debt was 106.9 billion dollars, over twice the amount of short-term liabilities to banks. Schwartz \& Whitcomb, supra note 3, at 257. See also Van Home, supra, at 437-39.

${ }^{11}$ This law is described in detail in Grant Gilmore, Security Interests in Personal Property 24-286 (1965).
} 
of debt secured by personal property. ${ }^{12}$ As a result, secured creditors are allegedly taking more and broader security interests than previously. ${ }^{13}$

Article 9 reduces the costs of becoming secured primarily by relaxing legal requirements for creating liens. An agreement to give a security interest ordinarily must be written, but the writing need contain only language of grant and a description of the collateral. ${ }^{14}$ The description, moreover, must only "reasonably identify what is described." 15 The code also reduces the cost of giving public notice of the existence of a security interest. The secured party must file in a public record of fice a "financing statement," but this document only has to identify and give the addresses of the secured party and debtor and again "reasonably" describe the collateral. ${ }^{16}$

Significantly, article 9 also reduces the costs of taking security interests in "after-acquired property." A creditor who lends on the basis of in-

12 The comment to U.C.C. § 9-101 recites:

"The aim of this Article is to provide a simple and unified structure within which the immense variety of present-day secured financing transactions can go forward with less cost and with greater certainty."

${ }^{13}$ U.C.C. § 9-204, comment 2, refers to "a feeling, often inarticulate in the [judicial] opinions [prior to the code], that a commercial borrower should not be allowed to encumber all his assets present and future, and that for the protection not only of the borrower but of his other creditors a cushion of free assets should be preserved." The comment states that this "premise has much to recommend it" but is rejected in article 9 because secured creditors had actually managed to lien everything: "The cushion of free assets was not preserved." Id. Professor Countryman, a strong critic of the code, had a different view of its effect:

"My theme for today is inspired by what many practitioners and bankruptcy referees tell me about the impact of the Uniform Commercial Code upon bankruptcy proceedings. They report that with the Code now in effect in every state but Louisiana, more and more bankruptcy cases emerge with every scrap of the bankrupt's property covered by some sort of a Code security interest so that nothing is left even for the payment of expenses of administration. That means, of course, that nothing will be distributed to any unsecured creditor, with or without priority."

Vern Countryman, Code Security Interests in Bankruptcy, 75 Com. L. J. 269 (1970). Professor Countryman's view of the code's effect is shared by the leading bankruptcy treatise. See 2 Collier on Bankruptcy, 363.01 (15th ed. 1979). A claim that unsecured creditors should receive more favorable treatment in bankruptcy than they now do can be maintained even if the code's historical view is correct.

${ }^{14}$ U.C.C. \& 9-203 (1). Agreements to give possessory security interests, in which the creditors take physical possession of the collateral, may be oral. Id. Apart from pledges of financial instruments, possessory security interests have little commercial significance.

${ }^{15} I d$. at $\S 9-110$. The accompanying comment states that "courts should refuse to follow the holdings, often found in the older chattel mortgage cases, that descriptions are insufficient unless they are of the most exact and detailed nature. . . "

${ }^{16}$ Id. at $\$ \S 9-401,9-402$. The code is thus a "notice filing" statute, where "the notice itself indicates merely that the secured party who has filed may have a security interest in the collateral described. Further inquiry from the parties concerned will be necessary to disclose the complete state of affairs." Id . at §9-402, comment 2 . 
ventory or accounts receivable is lending on a wasting asset because the inventory or accounts existing when the loan was made will soon disappear. Pre-code law sometimes required a secured party to give public notice of its interest in each new item of collateral as the debtor received it, ${ }^{17}$ a costly requirement with such rapid turnover items as inventory and accounts. The code, however, allows a financing statement to be effective notice of a creditor's interest in collateral existing when the credit was extended and in "after-acquired" collateral. ${ }^{18}$ Further, the new Bankruptcy Act, settling a dispute that existed under prior law, makes security interests in after-acquired property commonly enforceable in bankruptcy if the property is inventory or accounts. ${ }^{19}$ Most security interests in after-acquired property are in collateral of this kind. In addition, article 9 makes a financing statement effective for five years from the date of filing. ${ }^{20}$ Thus, if a particular debt is fully paid, the creditor commonly can make another loan without giving a second public notice or obtaining a new security agreement. ${ }^{21}$ These provisions of the code and the Bankruptcy Act rest on the premise that secured debt increases welfare, and they implement this premise by making secured debt much less costly to buy. Further, because secured creditors come first in bankruptcy liquidations, the code reforms significantly advantage secured at the expense of unsecured debt. ${ }^{22}$

17 See id. at $\S 9-204$, comment 1 .

${ }^{18}$ Id. at $\S 9-204$ (1).

19 Bankruptcy trustees had claimed under the old Bankruptcy Act that security interests in after-acquired property were preferential, that is, unlawful and hence subject to nullification by the trustee. When the debtor took possession of collateral which became subject to a previously granted security interest, the debtor in effect was transferring property to the creditor for an antecedent debt; the debt was the original credit extension. The circuit courts rejected this claim, although on rather questionable grounds. See, e.g., Du Bay v. Williams 417 F.2d 1277 (7th cir. 1969); Grain Merchants of Indiana v. Union Bank and Savings Co., 408 F.2d 209 (1969), cert. denied 396 U.S. 827 (1970). The Bankruptcy Act, in $\S 547(c)$, eliminated all doubt by providing that promptly perfected after-acquired security interests in accounts receivable and inventory were not preferential. This development is extensively discussed in Anthony T. Kronman, The Treatment of Security Interests in After-Acquired Property under the Proposed Bankruptcy Act, 124 U. Pa. L. Rev. 110 (1975).

20 U.C.C. $\$ 9-403$ (2).

21 A code security agreement may authorize the secured party to make "future advances" on the original collateral. U.C.C. $\$ 9-204$ (3). See also id. at $\S 9-204$, comment 5.

22 Secured creditors do worse than this description suggests if a possibility exists that the debtor may be reorganized rather than liquidated. Section 362 of the Bankruptcy Act automatically stays the enforcement of security interests on the filing of a bankruptcy petition. The stay will be terminated in a month if there is no prospect of an effective reorganization, but courts are quite lenient in giving debtors time to come up with reorganization plans. Even when no reorganization occurs, secured creditors may have to wait six months or more to foreclose. While courts are supposed to accord "'adequate protection" to secured parties during this interim (Bankruptcy Act $\$ 361$ ), they may not do so. See text at notes 43-47 infra. 


\section{Efficiency Explanations of Short-Term Secured Debt}

\section{A. The Problem}

Firms issue and creditors buy secured debt when the private gains from doing so exceed the costs. An efficiency explanation of secured debt must show when this is so and also that the social gains from security exceed the social costs. The conventional efficiency story is that high risk firms prefer issuing security because it enables them to borrow, and creditors prefer buying it because it enables them to make loans they otherwise would refuse. ${ }^{23}$ Security has these properties because it reduces the risks of creditors in the event of default, largely by allowing the secured party to take the property subject to its security interest and sell it to reduce or eliminate the debt. ${ }^{24}$ As we have seen, the power to seize and sell often survives the debtor's bankruptcy.

This conventional story seems unpersuasive if creditors (i) can learn of and react to the existence of security; (ii) can calculate risks of default reasonably precisely; (iii) are risk-neutral; and (iv) have homogeneous expectations respecting default probabilities. To see why this is so, it is helpful to consider more precisely just how secured financing reduces a creditor's risks. A lender that extends credit on an unsecured basis looks not only to the debtor's earning capacity for repayment but also to the debtor's assets. When a creditor becomes secured, however, certain (or all) assets of the debtor are set aside to help insure that this creditor is paid; in consequence, its chance of collecting its debt are much increased. And when these assets are removed from the general pool, the chance that the debtor's unsecured creditors will collect their debts correspondingly decreases. If all creditors are informed, the secured creditor will charge a lower interest rate because it is secured, whereas the unsecured creditors will charge higher interest rates because the pool of assets available to satisfy their claims has shrunk. The debtor's total interest bill is thus

Further, if the debtor actually is reorganized, the secured creditor may be required to take stock in the new enterprise. While the face value of the stock often equals the value of the unpaid debt, the shares of reorganized firms commonly trade at large discounts. See Jerold B. Wamer, Bankruptcy, Absolute Priority, and the Pricing of Risky Debt Claims, $4 \mathrm{~J}$. Financial Econ. 239, 244 n.7 (1977). Nevertheless, secured creditors seem to do relatively better than general creditors, even given the possibility or fact of reorganizations.

${ }^{23}$ A standard authority asserts that firms that pose a nonnegligible risk of default often "cannot obtain credit on an unsecured basis . . . . In order to make a loan, lenders require security so as to reduce their risk of loss." Van Horme, supra note 10 , at 458 . This explanation presupposes that creditors would refuse loans rather than lend unsecured at higher interest rates. The assumption is common but undefended. Its validity is not relevant to the analysis about to be made, which focuses on the response of unsecured creditors to the existence of security.

${ }^{24}$ U.C.C. $\S \S 9-503,9-504$. 
unaffected by the existence of security. Since the issuance of secured debt is itself costly, however, the debtor would be worse off with security than without it. Firms would never sell secured debt.

This unintuitive conclusion is illuminated by a somewhat more formal argument. Suppose the interest rate charged by a creditor to be partly a function of the risk of default. The premium that the creditor exacts to bear this risk, called $X$, can be quantified by the equation: $X=p(-P+$ $b A$ ). In the equation, $p$ is the probability that the debtor will default and $-P$ is the amount of a particular loan that will be lost if default occurs. The second term within the parentheses, $b A$, represents the value of the assets expected to be available to satisfy the creditor's claim at the time of default: $b$ is the ratio of the creditor's claim to the then total outstanding debt, and $A$ is the value of the total assets then supposed to be available to satisfy creditor claims. ${ }^{25}$ The equation thus captures the familiar idea that the risk of default is a function of its probability $(p)$ times the loss which default causes; this loss is a function of the value of the lost loan $(-P)$ offset by the chance that assets can be seized to satisfy the debt $(b A)$.

Suppose that a firm wants to borrow $\$ 200$ from two risk-neutral creditors $\left(C_{1}\right.$ and $\left.C_{2}\right)$. It has $\$ 100$ in available assets and both creditors assume this value to be stable over time. These creditors also assign a one percent probability to default $(p=.01)$. Creditor $C_{1}$ is to lend $\$ 110$ and creditor $C_{2} \$ 90$. The firm has only two options, to borrow unsecured or to secure $C_{1}$. What portion of its interest rate will reflect the risk of default in either case? If the firm borrows unsecured, $p=.01$ for $C_{1},-P=\$ 110 ; b=$ $\$ 110 / \$ 200=.55 ; A=\$ 100$. So $X$ for $C_{1}=.01(-\$ 110+.55 \times \$ 100)=$ $-\$ .55$. For $C_{2}, B=\$ 90 / \$ 200=.45$. Thus $X$ for $C_{2}=(-\$ 90+.45 \times \$ 100)$ $=-\$ .45$. And $X C_{1}+X C_{2}=-\$ 1.00$ : the possibility of default will cause creditors to increase interest charges to the firm by $\$ 1.00$.

${ }^{25}$ Should a firm become bankrupt, its creditors are paid on a pro rata basis: if the firm owes $\$ 100$ in total, $\$ 10$ of which is owed to creditor $A$, creditor $A$ is entitled to ten percent of the firm's assets to satisfy its claim. The text's equation presupposes a bankruptcy liquidation because this is what the textual equation grants. If creditor A collected before bankruptcy and before other creditors, however, it might be paid in full. On the other hand, if creditor A were last on line in a pre-bankruptcy distribution, it would get nothing. The text's equation is thus inaccurate in presupposing a bankruptcy-style liquidation. The equation should instead define the expected value of the assets available to a creditor on default by use of a set of terms characterizing the likelihoods and probable payoffs of a bankruptcy distribution in contrast to a first-come-first-served distribution. The text uses the simpler equation because it aids exposition without vitiating the point for which the equation is used. Also, institutional arrangements make bankruptcy-style liquidations likely. In particular, sections 547 and 548 of the Bankruptcy Act require creditors to turn over to the bankrupt estate payments received by them shortly before bankruptcy and made while the debtor was insolvent. Because of these sections, creditors may of ten anticipate bankruptcy-style liquidations when calculating risks of default. 
The firm's other option is to secure $C_{1}$. If this were done, $C_{1}$ would receive all assets on default. Then $X$ for $C_{1}=.01(-\$ 110+\$ 100)=-\$ .10$ : taking security reduces the premium $C_{1}$ would charge to insure against default from $-\$ .55$ to $-\$ .10$. Creditor $C_{2}$, however, would get no assets on default. In consequence, $X$ for $C_{2}=.01(-\$ 90+0)=-\$ .90$. Again, the premiums that $C_{1}$ and $C_{2}$ will charge because of default sum to $\$ 1.00$. Thus, if the firm secured $C_{1}$, its total interest bill would be unaffected: the interest premium it would pay because of the possibility of default would be $\$ 1.00$, whether $C_{1}$ is secured or no one is. The firm, however, would not be indifferent between issuing security and not issuing it. Issuing security is itself costly because the parties would have to negotiate a security agreement, give public notice, and so forth. Call these costs $S$. Then, without security, the portion of the firm's interest charges attributable to the risk that it might default would be $\$ 1.00$. With security, its cost would be $\$ 1.00+S$. Since $S$ represents a cost to the firm without any offsetting gain, the firm would not issue secured debt. And, to generalize, firms would never sell secured debt but would instead pay interest rates that reflect their risk category; high risk firms would pay high interest rates ( $p$ is greater so $X$ is greater) while low risk firms would pay low interest rates.

This conclusion is the logical consequence of the assumptions made above about creditor knowledge, ability, risk neutrality, and homogeneity of expectations. Because short-term secured debt is often seen, however, something must be going on that is not accounted for in the above analysis or the assumptions themselves are too restrictive. Sections B, C, and D of this part next consider what else could be going on: Part II-E then explores the consequences of relaxing the assumptions that creditors are risk-neutral, can calculate default risks relatively precisely, and have homogeneous expectations. ${ }^{26}$

\section{B. Monitoring Costs}

Part II-A purportedly showed that security increases the costs of unsecured creditors by as much as it reduces the costs of secured creditors; in

${ }^{26}$ The assumptions that the text makes are similar to the assumptions underlying the famous proof that in a perfect capital market a firm cannot increase its value by altering its capital structure. See Haley \& Schall, supra note 1, at 280 . The argument above may be thought of as a proof that a firm cannot increase its value by varying the nature of its debt instruments. This analysis does not depend on the ability of investors to arbitrage between firms but rather on the ability of a firm's creditors to vary interest rates with changes in the nature of the firm's debt. If the creditors could not do this, arbitrage possibilities are likely to yield the same result. The argument above, unlike the standard irrelevance proof, is robust to the existence of corporate taxes since the tax laws permit the deductibility of interest on 
consequence, firms have no incentive to issue it. The monitoring-cost explanation for the existence of secured debt attempts to show how security actually can increase the costs of unsecured creditors by less than it reduces the costs of secured creditors, even if the assumptions made above of creditor knowledge, ability, risk neutrality, and homogeneous expectations hold ${ }^{27}$ Recall that interest rates are partially a function of the risk of default, and that this risk is itself a function of the riskiness of the debtor's business. Suppose a firm borrows money at an interest rate that accurately reflects the risk of its enterprise. After the loan is made, the firm pursues a higher risk project for which a higher interest rate would have been charged. The firm has thus retroactively reduced the interest rate it faces: it is borrowing at a low risk rate for a high risk project. Firms with limited shareholder liability sometimes would so act because they would capture most of the gains if a high risk project pays off but bear only part of the losses if it does not. Creditors would bear the rest of these losses.

Creditors know that debtors have incentives to reduce interest rates retroactively by taking greater risks. To prevent or limit such debtor misconduct, they can (and do) monitor debtors-that is, watch and police them. Monitoring, however, is expensive. A security interest is then explicable as a device to reduce creditor monitoring costs. If a creditor is fully secured, it need only monitor to ensure that the assets subject to its security interest are not dissipated; it need not monitor the debtor's entire business to prevent the debtor from taking risks not justified by the operative interest rate.

The monitoring-cost explanation for the existence of secured debt, as so far described, is similar to the conventional risk-reduction explanation analyzed above. It shows how security reduces the costs of the secured creditor but ignores the impact of security on the unsecured creditors. Monitoring costs aside, these creditors apparently experience cost increases from security that match the cost reductions that security generates. Also, although security may reduce the secured party's monitoring costs, it seems likely to increase the monitoring costs of unsecured creditors. The existence of security raises the expected cost of default for unsecured creditors by reducing the available asset pool and thus creates incentives for these parties to monitor more extensively. A

both secured and unsecured debt. A variety of debt instruments do exist, however, and the text explores possible explanations for their existence.

${ }_{27}$ Monitoring-cost explanations for the existence of secured debt are found in Thomas $\mathrm{H}$. Jackson \& Anthony T. Kronman, Secured Financing and Priorities among Creditors, 88 Yale L.J. 1143 (1979); and Clifford W. Smith, Jr. \& Jerold B. Wamer, Bankruptcy, Secured Debt, and Optimal Capital Structure: Comment, 34 J. Finance 247 (1979). 
monitoring-cost theory therefore must also explain why the secured creditor gains more from security than the unsecured creditors lose from it. $^{28}$

A way to show that security can reduce a firm's net credit costs is to focus on the methods by which a firm can behave in a more risky fashion after a loan is made. Sometimes, taking greater risks requires a firm to exchange assets for other assets. A firm that wants to switch from making lathes to making amphibious cars, for example, will need different machinery. A security interest in the firm 's property would impede such a substitution of assets by drying up the market for the firm 's equipment. The code provides, in $\S 9-306(2)$, that "a security interest continues in collateral notwithstanding sale, exchange or other disposition thereof unless the disposition was authorized by the secured party . . . . In consequence, people would be deterred from purchasing equipment from misbehaving firms. Since asset substitution is an important method of behaving more riskily after a loan is made, security reduces the risk of a debtor's misbehaving. Most significantly, it reduces this risk not only for secured parties but for anyone who extends credit to the firm. The increase in monitoring costs that unsecured creditors experience as a result of security may thus be less than the decrease in monitoring costs that the secured party incurs: indeed, where asset substitution is the principal method of behaving more riskily, the absolute level of monitoring by unsecured creditors could decline. ${ }^{29}$

This explanation of the existence of secured debt, however, is unpersuasive when applied to short-term financing because the kind of

${ }^{28}$ Jackson and Kronman argued that certain groups of creditors-in particular, suppliers-can acquire and assess information about the debtor's post-loan behavior at less cost than other groups of creditors-in particular, banks-because the former group has more knowledge about the debtor's industry. See Jackson \& Kronman, supra note 27, at 1159-60. They then argued that securing the creditors with relatively high informationacquisition costs reduces total monitoring costs. The argument is interesting but subject to two difficulties. First, suppliers of inputs to debtors whose affairs are complex may have less ability to obtain and evaluate information about the debtors ${ }^{\circ}$ post-loan behavior than the debtors' bankers have. For example, a seller of office machinery to the Ford Motor Company seems less able to evaluate changes in Ford's plans to manufacture cars abroad than Ford's financial creditors, which study the entire company before making loans. The Jackson-Kronman theory thus predicts that suppliers to complex businesses will be secured more frequently than suppliers to simple or single-line businesses. Commentators, however, do not report observing such a trend. Further. if the debtor maintains its business bank account at the bank that finances it, as often occurs, the bank may be able to leam of important changes in the debtor's affairs more promptly and in greater detail than could other creditors. Second. the Jackson-Kronman argument is subject to many of the difficulties that attend the asset-substitution theory discussed next.

${ }^{29}$ This explanation follows from Smith \& Wamer, supra note 27, who claim that secured debt is issued because it "is one way of precluding asset substitution by borrowers." $1 d$. at 250. 
monitoring for which security is supposedly a substitute often seems unnecessary in this case. Suppose that creditors can observe at relatively low cost the significant asset substitutions by a debtor that materially alter the riskiness of the debtor's enterprise. A creditor can react to the possibility of such substitutions in two ways: it can monitor its debtor fairly extensively to reduce the likelihood of the debtor's misbehavior, or it can rely on the sanction of lost good will to induce the debtor not to misbehave. A firm that behaves in a riskier fashion after a loan is made shows itself to be untrustworthy, and its ability to obtain future loans is impaired. Lost good will would seem of particular concern to a debtor that primarily uses short-term financing. Such a firm must enter the credit market frequently and is likely to regard the good-will cost from asset substitutions as high in relation to the retroactive interest-rate reduction that those substitutions produce on existing loans. Thus the creditors of such a firm probably would choose to incur the relatively low cost of invoking the good-will sanction by observing whether significant asset substitutions have occurred, rather than the relatively high cost of policing to prevent this form of misbehavior. Security interests are expensive, however, and seem substitutes only for the high cost version of monitoring-that is, policing for preventive purposes. Creditors have an incentive to engage in this form of policing during long-term financing situations, where the debtor's good-will costs from misbehavior are relatively less. The monitoring-cost explanation therefore predicts that firms may issue secured debt when much of their financing is long-term but will seldom do so when they primarily use short-term credit. The relatively large amount of short-term secured debt issued by retailers thus constitutes a serious counterexample to the monitoring-cost theory. ${ }^{30}$

That short-term debt sometimes has many of the characteristics of long-term debt is an insufficient response to this difficulty. Short-term debt is considered long-term debt for some purposes when a debtor and particular creditor form a relatively permanent association. As an example, a bank may finance a particular retailer for many years, taking security interests in its (everchanging) inventory and accounts receivable.

\footnotetext{
${ }^{30}$ The costs of misbehavior to debtors vary directly with the ease with which potential creditors can learn of that misbehavior. In small towns, few institutional lenders exist, and communication among these lenders consequently is easier than among lenders in large cities. As a result, the good-will sanction is apparently effective against any small-town firm that uses primarily short-term financing and contemplates remaining in business for some time. Yet such firms sometimes issue short-term secured debt. The monitoring-cost explanation predicts that this practice would seldom occur. Creditors also may monitor to prevent fraud. Selling property subject to an inventory security interest to a consumer is permitted, for example, but not remitting the agreed portion of the proceeds to the secured creditor is prohibited. Security interests apparently would not reduce the risk of such fraud by much, and so do not seem substitutes for monitoring directed at it.
} 
Banks, however, extend funds on a periodic basis in such relationships and will terminate if the firm behaves more riskily. Moreover, such a creditor can conveniently learn of important changes in its debtors' businesses. Thus even in these "long-term" financing situations the good-will costs of debtor misbehavior seem sufficiently high to make questionable the monitoring-cost explanation for the existence of secured debt.

This explanation also fails to hold because the danger of asset substitutions that secured debt is supposedly meant to prevent varies with the length of the loan. A short-term creditor would commonly perceive significant asset substitutions to be of relatively low probability. Firms, it is true, sometimes do significantly alter their affairs during the course of their lives, but such fundamental changes take time. A creditor holding a one-year note, for example, is therefore likely to assume that its debtor would be in roughly the same line of work at year's end. ${ }^{31}$ Thus again short-term creditors would have little incentive to take security as a substitute for incurring high monitoring costs.

To summarize, the monitoring-cost explanation for the existence of secured debt will hold when unsecured creditors can freeload on the property of security to impede asset substitutions. When such freeloading occurs, security reduces the costs of secured creditors by more than it increases the costs of unsecured creditors, thereby creating an incentive for firms to issue it. Freeloading apparently would not occur, however, when firms primarily use short-term financing because short-term creditors would seldom need to monitor to reduce the odds of significant asset substitutions. The sanction of lost good will would often induce debtors not to engage in such substitutions when their financing is primarily short-term, and short-term creditors are likely to perceive asset substitutions as rare events during the course of their loans. When security does not substitute for monitoring to prevent misconduct, it neither reduces the monitoring costs of those who take it nor benefits those otherwise disadvantaged by it. The monitoring-cost explanation therefore pre-

31 This statement seems too broad. Retailers sometimes can increase the risk of their enterprise relatively easily by varying the nature of their inventory - from children's blocks to hula hoops. A security interest in such a firm's inventory, however, would not materially reduce the risk of this conduct. Inventory security interests permit firms to sell the goods, with the security interest shifting to the proceeds of sale. Thus the firm could sell the blocks it owned initially, and the security interest would not bar it from replacing them with hula hoops. With short-term loans, therefore, security would not reduce the risk of asset substitutions in one of the principal cases in which they might arise. Professors Jackson and Kronman state that security is more likely to be issued in connection with long-term loans than with short-term loans, but do not note the difficulties that this possibility creates for a monitoring-cost explanation of short-term secured debt. See Jackson \& Kronman, supra note 27 , at 1159 . 
dicts that firms will seldom issue secured debt when their financing is primarily short-term and it is thus seriously embarrassed by the substantial amount of secured debt that retailers issue.

\section{Secured Debt as a Signal}

A second explanation for the existence of secured debt that also is consistent with the assumptions made about creditor knowledge, ability, risk neutrality, and homogeneity of expectations is that firms issue security as a "signal" to creditors of their prospects. Signaling explanations for the financing decisions of firms are becoming common and seem promising. ${ }^{32}$ At this stage in their development, however, signaling models are unsatisfactory because it is difficult to know whether a particular activity is a signal and whether a particular signaling outcome is efficient.

To perceive the promise and problems of a signaling explanation for the issuance of secured debt, first suppose that at a given time firms seek to finance a set of projects whose outcomes are highly variable. Firms know the "quality" - for example, the outcome mean and variance-of their own projects, but creditors cannot distinguish among firms on the basis of quality. This asymmetry of information could occur because the quality of a particular project is a function of facts and prospects that outsiders can observe only with great difficulty. Further, the firm has an incentive to overestimate the likelihood of favorable outcomes. In this circumstance, interest rates in the loan market would reflect average project quality. Moreover, were the market to set interest rates that reflect a relatively high average quality (higher than the average risk of projects), firms would supply large numbers of low quality projects. This is because firms with low quality projects could borrow at rates that reflected risks below the actual risks their projects faced; such firms would make substantial gains at the expense of creditors. Creditors, however, are aware of this possibility and, when they lack information about the quality of particular projects, will suppose average project quality to be relatively low. In this

32 See Sudipto Bhattacharya, Imperfect Information, Dividend Policy, and " the Bird in the Hand" Fallacy, 10 Bell J. Econ. 259 (1979) (explaining the issuance of dividends as a signal to creditors of a firm's owners' true estimate of future earnings): Stephen A. Ross, The Determination of Financial Structure: The Incentive-Signalling Approach, 8 Bell J. Econ. 23 (1977) (same); Hayne E. Leland \& David H. Pyle, Informational Asymmetries, Financial Structure, and Financial Intermediation, 32 J. Finance 371 (1977) (explaining the equity position that a firm 's owners take as a signal to creditors of the owners' true estimate of the profitability of the firm's projects). See also, Stephen A. Ross, Some Notes on Financial Incentive-Signalling Models, Activity Choice, and Risk Preferences, 33 J. Finance 777 (1978). The evidence relevant to the dividend-signaling explanation seems inconclusive. See Thomas Copeland \& J. Fred Weston, Financial Theory and Corporate Policy 359-62 (1979). 
event, firms with projects of higher quality than the market average could not get credit on accurate terms. These firms thus have an incentive to inform creditors of - that is, to "signal" - their relative status.

An effective signal must enable its observers to sort out the signalers by some criterion that the observers consider relevant. This signaling property probably exists in credit markets if the cost of signaling a firm 's risk status declines as the quality of the firm's projects increases. This is because, if project quality were uncorrelated with signaling costs, firms with low quality projects would send out signals of high quality and creditors would learn to disregard the signal as a mark of quality.

A security interest might be such an effective signal. Security interests restrict future borrowing opportunities, give secured creditors greater leverage over firm behavior, and make it more difficult for a firm to reschedule debts in the event of hard times. A firm willing to encumber its assets is, thus, "signaling" that, in its view, its prospects justify these potential costs. Further, signaling costs apparently vary inversely with project quality because they are partly a function of the likelihood that the firm will experience financial difficulty. A firm likely to earn high profits may worry little about the future restrictions on its ability to borrow that a security interest may create or about the power that a security interest gives to a creditor to influence firm decisions if no profits are realized. Firms expecting not to do well, on the other hand, may regard the expected costs of issuing secured debt as high because those costs could well be incurred. The apparent property of secured debt to communicate accurately to creditors a firm's true estimate of its expected earnings indicates that the existence of secured debt may be explained as a signaling phenomenon. The information conveyed by the issuance of secured debt enables firms to borrow on terms that more accurately reflect their risk classes.

This explanation is plausible if creditors actually have an incentive to use the signal over time and firms have an incentive to signal correctly. To perceive the circumstances under which these conditions may be met, suppose that $Z$ is an unobservable variable reflecting the project quality of a particular firm. This variable has the property that, if firm one has a higher quality project than firm two, $Z_{1}>Z_{2}$. Let $Y$ be the signal that firms send for project quality. Creditors initially believe, for the reasons given above, that a higher $Y$-a security interest that encumbers more assets or encumbers assets for longer periods of time-correlates positively with higher quality. For example, creditors initially believe that a firm that signals $Y_{1}$ has project quality $Z_{1}$. If such a firm would actually maximize profits by signaling $Y_{1}$ when it has quality $Z_{1}$, the creditors' beliefs are confirmed. In this case, the market will reach a "signaling equilibrium": 
creditors will use the signal because they attribute informational content to it that their experience confirms and firms have an incentive to signal correctly.

A relatively simple example shows that such a signaling equilibrium might occur. ${ }^{33}$ Suppose that two groups of firms exist, those with low quality projects (Group I) and those with high quality projects (Group II). It costs a firm in Group I $\$ Y$ to grant a particular security interest and a firm in Group II $\$ Y / 2$ to issue the same security interest. High quality firms in Group II have lower signaling costs if, as argued above, these costs vary inversely with project quality. Creditors in this illustration initially believe that a firm that gives a security interest of type $Y^{\prime}$ is risky enough to require an interest charge of $\$ 10$ for its loan while a firm that grants a security interest of type $Y^{\prime \prime}$ is sound enough to justify an interest charge of $\$ 5$ for the same loan. Given these creditor beliefs, Group I firms will not grant security interests of type $Y^{\prime}$ if $10<5+\$ Y$. Group II firms will grant a security interest of type $Y^{\prime \prime}$ if $5+\$ Y / 2<10$. Combining these inequalities, when $\$ 5<\$ Y<\$ 10$, creditor beliefs about project quality are confirmed. For example, if creditors initially associate a high quality project with a security interest of type $Y^{\prime \prime}$ that would cost Group I firms $\$ Y$ $=\$ 7$ to grant, they will observe in the market that firms with low quality projects signal $Y^{\prime}$ and firms with high quality projects signal $Y^{\prime \prime}$, a confirming set of signals. ${ }^{34}$

This illustration is too simple because of the crudity of creditor beliefs and because of the discreteness of the intervals chosen: project risks supposedly are such that interest charges of $\$ 5$ or $\$ 10$ only are justified. Nevertheless, equilibrium signaling schedules have been shown to exist when more sophisticated beliefs are attributed to creditors and less "lumpy" variables are assumed.$^{35}$ These schedules have the property that a continuum of prices (here interest rates) exists, conditional upon the level of the signal, such that when firms acting as price takers choose their maximizing signal level, creditors find that their quality forecasts are confirmed. Such a schedule might look like curve $F F$ in Figure 1.

${ }^{33}$ The example is derived from A. M. Spence, Market Signaling: Informational Transfer in Hiring and Related Screening Processes 16-20 (1974).

${ }^{34}$ For those interested in how the numbers work out, a firm in Group I would not signal $Y^{\prime \prime}$ when $\$ Y=\$ 7$ because it would cost this firm $\$ 7$ to send the signal while the signal would generate an interest-rate reduction of only $\$ 5$ (from $\$ 10$ to $\$ 5$ ). A firm in Group II would signal $Y^{\prime \prime}$ because its signaling cost is $Y / 2=\$ 3.50$ and the signal yields a rate reduction of $\$ 5$. A Group II firm would not issue a security interest that would cost it more than $\$ 3.50$ because creditors in the example above charge $\$ 5$ to all firms that signal $Y^{\prime \prime}$ or more; thus sending a signal costing more than $\$ 3.50$ would generate no gains.

${ }^{35}$ See, e.g., Leland \& Pyle, supra note 32; John G. Riley, Informational Equilibrium, 47 Econometrica 331 (1979). 


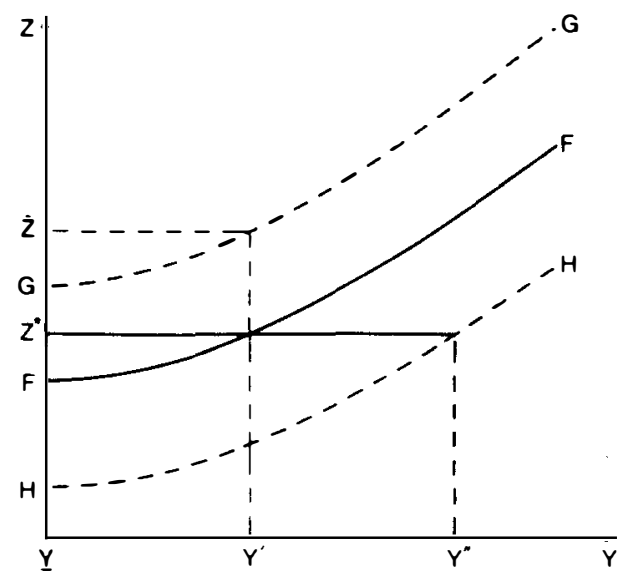

FIGURE 1

In Figure 1, the level of the signal-the breadth and length of a security interest-is plotted on the horizontal axis and project quality-the firm's prospects-on the vertical axis. To show that only one signaling schedule can exist in equilibrium, first consider a second schedule, $G G$. A firm with quality level $\tilde{Z}$ would signal $Y^{\prime}$, as would a firm with quality level $Z^{*}$, where $\bar{Z}>Z^{*}$; thus the signal $Y^{\prime}$ would be useless to creditors. Put another way, the assumption that signaling cost varies inversely with project quality is violated by the existence of the schedule $G G$, for that schedule permits low quality firms to "mimic" the signals of high quality firms: both such firms here would signal $Y^{\prime}$. Now consider the schedule $H H$. A firm with quality $Z^{*}$ could signal this to creditors by taking a security interest of the value $Y^{\prime}$ (along $F F$ ) or $Y^{\prime \prime}$ (along $H H$ ), but $Y^{\prime}<Y^{\prime \prime}$. Firms thus would prefer to be on $F F$ because the same level of quality can be signaled at lower cost on this schedule than on any schedule to the right of $F F$ in Figure 1. Thus an equilibrium-signaling schedule in a given credit market must be unique.

To summarize the signaling explanation, firms have an incentive to issue secured debt as a way of sorting themselves out by risk class if creditors take the existence and level of secured debt as indicia of firm profitability. Creditors may hold such beliefs because secured debt is more costly for firms to issue when their projects are of low quality. Further, profit-maximizing firms have an incentive to signal in a way that confirms creditor beliefs about the relationship between the existence and level of security and the prospects of firms.

This signaling explanation is promising but, unfortunately, has serious difficulties. A security-interest signal may be ambiguous because it re- 
quires creditors to know the risk preferences of firm owners. ${ }^{36}$ To see why this is so, suppose two firms have identical prospects $-Z_{1}=Z_{2}$. The owners of firm one are risk preferers; they are relatively unconcerned about granting broad security interests because they count the marginal benefits from potential gains more heavily than the marginal costs from potential losses. Firm two's owners, however, are risk-averse; they take seriously the costs that a broad security interest could impose on them. Firm one, consequently, could issue a broader security interest than firm two-signal $Y_{1}>Y_{2}$-although in fact $Z_{1}=Z_{2}$. The security-interest signal would then be useless and creditors would not rely on it. The signaling-cost explanation for the existence of secured debt thus rests on the seemingly strong assumption that owners of firms in any given market have roughly similar attitudes toward risk.

Whether a security-interest-signaling equilibrium increases welfare is hard to know. Firms will signal if their gains from doing so exceed their costs, but whether the social gains exceed the social costs is a separate question. The private gain to a firm from signaling, assuming creditors use security-interest signals, is the reduction in the interest rate the signal generates. The social gain is that the signal helps produce better "matches" between creditors and firms: the amount and cost of credit more closely approximate their "true" levels with signaling than without it. If a security-interest signal, however, actually tells creditors little about the riskiness of firm projects, too much signaling could occur in equilibrium: the total costs that firms incur in sending signals will exceed the total social gain generated by more appropriate credit extensions. Security interests seem relatively crude devices for information transmission so the chance that they actually reduce welfare is nonnegligible. But the important point is the difficulty in knowing whether too much signaling will occur in equilibrium. Finding out requires a comparison of the accuracy of creditor assessments of firms ' projects in a no-signaling world with the assessments that are made by use of security-interest signals. At this stage, no theory is suggestive of the outcome of such a comparison, in general or in particular cases, nor have the relevant facts been obtained.

Answering the welfare question is difficult for another reason: signaling equilibria often appear unstable, and this instability may make unfeasible

\footnotetext{
${ }^{36}$ Ross makes the same criticism of Leland and Pyle's model, which asserts that the equity positions owners take in their own firms operate as signals of the owners' true predictions of their firms ${ }^{\circ}$ prospects. See Discussion, 32 J. Finance 412 (1977). Deciding whether signaling occurs in real-world markets is difficult. For illustrations of recent attempts, see James W. Albrecht, A Procedure for Testing the Signalling Hypothesis (1979) (Discussion paper \#28, Columbia Univ., Dep't of Econ.) (educational screening): John G. Riley, Testing the Educational Screening Hypothesis, J. Pol. Econ. (forthcoming).
} 
even rough comparisons between signaling and no-signaling worlds. ${ }^{37}$ To understand how signaling equilibria break up, suppose that all projects in the market will earn positive profits at the highest interest rates charged. Firms at the lower end of the market distribution for quality-those with the riskiest projects - signal $\underline{Y}$. With a rising quality distribution-higher quality firms grant more extensive security interests-the lower end firms actually form an interval, say from $\underline{Z}$, the lowest quality, to $\hat{Z}$, with average quality being $Z^{\circ}$. All these firms will signal $\underline{Y}$, however, because the costs of signaling a greater $Y$ would exceed the gains for those firms whose quality level is above but quite close to $\underline{Z}$. For firms that signal $\underline{Y}$, the market interest rate is $\underline{R}$. Suppose that a creditor offers an interest rate justified by the average quality level in the $\underline{Z}$. . . $\hat{Z}$ interval to any firm that signals $\underline{Y}$; the lender bids $R^{\circ}$ which correlates with $Z^{\circ}$. This creditor would make no gains from firms within the interval because it gets just that average quality on its debtors' projects that the interest rate justifies. But because the distribution of firms by quality does consistently rise, some firms whose quality is just above the interval $\underline{Z}$ to $\hat{Z}$ will exist who nevertheless signal $Y$ : for these firms also, the costs of signaling their true quality level-say $Z^{i}$-are too high. These relatively high quality firms will also borrow from our creditor because $R^{\circ}<\underline{R}$; and their appearance raises the average quality of this creditor's debtors. Thus a creditor who bids an interest rate slightly below the market minimum is assured of doing better than it would have done if it offered the minimum rate. The lower bid generates debtors with an average project quality greater than the bid actually justifies. The signaling equilibrium therefore "unravels

${ }^{37}$ Economists attempt to establish the nature of equilibria in their models because an equilibrium is a prediction of what actual market outcomes look like. If an analyst cannot characterize the features that a particular market would have in equilibrium, he will have difficulty assessing the welfare implications of the features he actually observes. For example, if he lacks a theory of what a credit market looks like in competitive equilibrium, he will find it hard to decide whether the particular credit markets that he sees are behaving competitively or not. The instability properties of signaling equilibria are now well known. See Riley, supra note 35; John G. Riley, Competitive Signalling, 10 J. Econ. Theory 174 (1975); Michael Rothschild \& Joseph E. Stiglitz, Equilibrium in Competitive Insurance Markets: An Essay on the Economics of Imperfect Information, 90 Q. J. Econ. 629 (1976). The equilibrium concept employed in all of these models is the Nash equilibrium. A system will be in a Nash equilibrium if each actor in it maximizes expected utility by pursuing his or her chosen strategy given that all other actors continue to pursue their chosen strategies. In this circumstance, the system is at an equilibrium, for no one in it has an incentive to do other than what he is doing. A set of strategies could not constitute an equilibrium if at least one actor has an incentive to vary his strategy, given that other actors continue to pursue their strategies. For a further explanation of the Nash equilibrium concept, see Alan Schwartz \& Louis L. Wilde, Intervening in Markets on the Basis of Imperfect Information: A Legal and Economic Analysis, 127 U. Pa. L. Rev. 630, 640-41 (1979). 
from the bottom," because creditors and firms have an incentive to depart from it at this point ${ }^{38}$

A signaling equilibrium may also unravel from within. ${ }^{39}$ Suppose that a firm with quality $Z^{i}$ above the market minimum signals $Y^{i}$. A creditor who offers an interest rate equal to the average in the interval $Z^{i} \ldots Z^{j}$, where $Z^{i}<Z^{j}$, will get some firms whose quality is greater than $Z^{j}$ for the reasons described above. The creditor will also get firms whose quality is below the $Z^{i} Z^{j}$ average, however, for at the lower rate these relatively low quality firms will benefit from raising their signals to the level $Y^{i}$. Whether the creditor has an incentive to break the equilibrium from within therefore depends on the slope of the distribution of quality by firms. If the number of high quality firms is increasing rapidly enough around the signaling point $Y^{i}$, the creditor will attract more good firms than bad ones with its lower bid. Internal unraveling is thus a function of a factor that is hard to characterize or observe, the slope of the distribution of project

${ }^{38}$ This argument may be made clearer with Figure 2. In the market, an interest rate of $\boldsymbol{R}$ in Figure 2-B is paid to creditors who signal $\underline{Y}$. Suppose a creditor bids $R^{\circ}$. which is justified by the average quality $Z^{\circ}$ in the interval $Z \ldots \hat{Z}$ in Figure $2-A$. This creditor makes no extra profits from firms in the interval, because the average quality of their projects correlates with a bid of $R^{\circ}$. The bid, however, is attractive to firms in the interval $\hat{Z}$ to just before $Z^{\prime}$ because $R^{\circ}<\underline{R}$; these higher quality firms also signal $\underline{Y}$ because the costs to them of signaling $Y^{\prime}$ are not justified by the difference between $R^{\prime}$, the rate for $Y^{\prime}$, and $R$. These relatively high quality firms also borrow from the creditor that bids $R^{\circ}$, so the ave rage quality of the firms this creditor gets is above $Z^{\circ}$. The bid $R^{\circ}$ thus ensures the creditor a net gain. This creditor need not be particularly astute; naive experimentation by creditors, who vary their bids out of ignorance of the market price or to see what happens, could produce equilibrium-breaking bids. The unraveling the text and this note describe occurs because the signaling variable is supposedly discontinuous; that is, not every slight increase in project quality is matched by a corresponding increase in the signaling level. If security-interest signals are discontinuous, a particular signal will apply to a range of quality levels, as the unraveling argument assumes. Security-interest signals are likely to have some discontinuity because of the difficulty of precisely matching increases in the collateral subject to them with increases in the quality of firm projects.
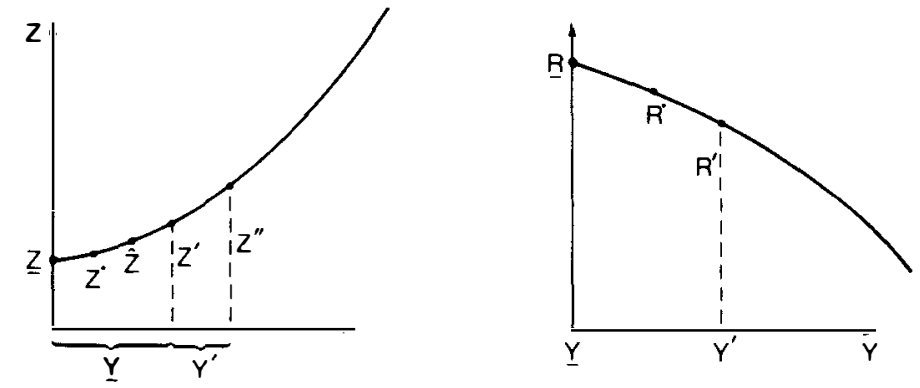

FIGURE 2

${ }^{39}$ See Riley, supra note 35 , at 343-46. 
quality by firms. ${ }^{40}$ To summarize, in consequence of the frequent instability of signaling equilibria at and above the lower bound, it is difficult to compare, either in theory or by empirical investigation based on theory, a particular signaling market with its no-signaling equivalent. Yet without such a comparison, assertions that signaling is efficient are essentially ad hoc.

These criticisms of the signaling explanation make two points. First, signaling may not account for the existence of secured debt because a security interest might be an insufficiently clear signal. Second, if firms issue secured debt as a signal, the social gains from such signaling have not been shown to exceed the social costs; also, such a showing seems hard to make because of the difficulty of testing signaling hypotheses empirically. Taken together, the criticisms demonstrate the present unpersuasiveness of a conclusion that security interests are efficient signals.

\section{Staggering Debt}

The last serious efficiency explanation for the existence of secured debt consistent with the assumptions made above about creditor knowledge,

${ }^{40}$ Leland \& Pyle, supra note 32, claim that finance market equilibria will not unravel at the lower bound. Id. at $379 \mathrm{n} .11$. To see their argument, Figure 1 should be redrawn as in Figure 3. Figure 3 presupposes that firms bring projects to market but do not signal, because at prevailing interest rates their projects are of such poor quality that the costs of signaling exceed the gains. These firms are on the signaling schedule $F F$ slightly to the left of the $Z$ axis. When a creditor in this circumstance offers a new bid to the low quality firms that are signaling $\underline{Y}$ (bids $R^{\circ}<\underline{R}$ ), its bid will cause some of the nonsignaling firms to signal $\underline{Y}$; for at $R^{\circ}$ the projects of these firms will earn positive returns given the signal $\underline{Y}$. In consequence of the potential appearance of these low quality firms, a creditor who bids $R^{\circ}$ is not assured of making gains because it will attract below average as well as above average firms. Leland and Pyle thus assert that the creditor has no incentive to break the signaling equilibrium by bidding $R^{\circ}$; the equilibrium will not unravel from below. This assertion is inaccurate. If low quality nonsignaling firms actually are in the market and would signal $\underline{Y}$ if a creditor bids $R^{\circ}$, the "end point" is actually a midpoint, and whether the equilibrium would unravel depends on the slope of the quality distribution. Specifically, if the slope were such that a bid of $R^{\circ}$ would attract more high than low quality firms, unraveling would occur. Leland and Pyle are correct, however, in observing that if the supply of low quality nonsignaling firms is sufficiently elastic around the lower end point, a signaling equilibrium will not necessarily unravel from below.

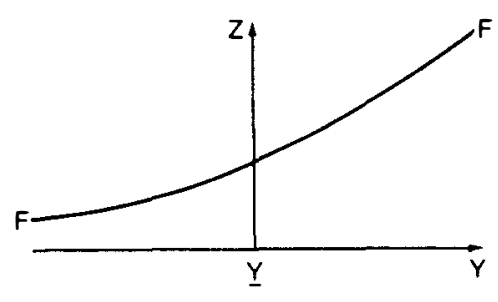

FIGURE 3 
ability, risk neutrality, and homogeneity of expectations follows from the premise that properly staggered debt can increase profits. Suppose a firm knows it will have credit needs over time and also knows reductions in the interest rates of secured debt will trigger corresponding increases in interest rates by unsecured creditors. The firm may borrow on a secured basis and later borrow on an unsecured basis. By so doing, it pays lower interest rates early and higher interest rates late. If the return earned by investing the difference between the secured and the unsecured interest rates exceeds the costs of granting security, the firm will issue secured debt. Such secured debt would also be efficient because the firm benefits while no one loses.

This staggering-debt explanation generates two predictions that appear inconsistent with the facts: firms whose debt frequently turns over will seldom issue secured debt, and firms that can profit from staggered borrowing will issue secured debt as early in their lives as possible. Respecting the first prediction, if a firm turns over its debt frequently, as when it continuously buys goods on credit, there would be little opportunity to earn a return sufficient to justify the cost of issuing security because the firm would experience higher interest rates from unsecured creditors quite promptly. Relatively small retailers seem to have frequent credit needs, yet such firms sometimes borrow on a secured basis. Respecting the second prediction, if a firm can earn positive profits by investing the interest rate differential between secured and unsecured debt, it has an incentive to issue secured debt first and later borrow unsecured. In this way it can capture these profits as soon as possible. Systematic patterns of firms' borrowing according to the pattern of issuing secured debt first have not yet been observed. Since the staggering-debt explanation yields predictions that the very sparse data apparently fail to support, its validity is questionable.

\section{E. Risk Aversion, Uncertainty, and Heterogeneous Expectations}

1. Risk Aversion. Security interests might increase welfare if they helped shift risks from more to less risk-averse creditors. Whether they play a significant role in performing this function is problematic. To see the relevance of a risk-aversion explanation, recall that the argument respecting why security would not reduce a firm's net credit costs presupposed that all creditors were risk-neutral. In the illustration in Part II-A, when neither $C_{1}$ nor $C_{2}$ were secured, they priced the default risk at its actual value, $\$ .55$ and $\$ .45$ respectively. Suppose instead that $C_{1}$ were risk-averse; to bear a $\$ .55$ risk it would charge the debtor $\$ .60$. Let $C_{2}$ remain risk-neutral; it would charge a risk's actual value whatever the 
level of the risk. Under these new assumptions, the interest-rate increase attributable to the risk of default when neither creditor is secured would be $\$ 1.05$. When $C_{1}$ became secured, its risk in the illustration above dropped to $\$ .10$ while $C_{2}$,s risk rose to $\$ .90$. Since risk aversion generally varies with the degree of risk, suppose that $C_{1}$ would only charge $\$ .01$ for bearing a $\$ .10$ risk. By securing the risk-averse creditor $-C_{1}$-and shifting risks to the risk-neutral creditor- $C_{2}$-the firm's net credit cost falls by $\$ .04$, from $\$ 1.05$ to $\$ 1.01$. This decline is a net welfare gain since the firm is made better off but no one is made worse off. And, to generalize, security is used to reduce a firm's net credit costs by shifting risks from more to less risk-averse creditors.

The risk-aversion explanation seems plausible, but has two serious difficulties. First, it fails to show why creditors respond to risk aversion by taking security. Taking security is costly, so risk-averse creditors may prefer to buy low risk debt directly rather than buy high risk debt and reduce its risk by mortgages. Since much low risk debt exists, the riskaversion explanation is incomplete. ${ }^{41}$ Second, given what is known about the goals that corporate managers actually pursue, explaining the existence of secured debt as a response to differential levels of risk aversion among creditors seems either mistaken or tautological. To perceive the nature of this difficulty, recall that risk aversion in individuals is explained by the diminishing marginal utility of money theory. This theory provides that each additional dollar a person receives generates less utility for him than the addition of earlier dollars did because later dollars are used to satisfy less urgent needs. Because money has diminishing marginal utility, a person seeking to maximize his or her expected utility would not be indifferent between equal prospects of gain or loss. The person would lose more utility if the loss materialized than he or she would gain if prospects were successful. That is, for an ordinary person the expected utility of being given an equal chance of winning or losing the same amount would be less than the utility of not gambling. The assumptions that individuals maximize expected utility and that money has diminishing marginal utility thus imply individual risk aversion, not risk neutrality.

Many of a firm's business creditors, however, are likely to be corporations that are operated by managers whose scope of operation is to some extent independent of shareholder preferences. What utility function these managers maximize is a controversial and unresolved question. Economists and lawyers commonly assume that the managers try to

${ }^{41}$ Jackson \& Kronman, supra note 27, also criticize the risk-aversion explanation on this ground. See id. at 1152 , n. 39. The criticism may not be fully justified, however, because creditors of ten choose to hold assets of different risk classes as a means of diversif ying their portfolios. 
maximize the market value of the corporation's stock. This goal implies risk neutrality. If managers are assumed to maximize share values, the risk-aversion explanation thus predicts that corporate creditors will be like $C_{2}$ in the example above. Being risk-neutral they will lend unsecured at relatively high interest rates so individual risk-averse creditors such as $C_{1}$ can become secured at relatively low interest rates. The substantial amount of short-term secured debt held by banks and finance companies thus constitutes a troublesome counterexample to the risk-aversion explanation. Suppose next that the assumption of corporate managers maximizing share values is abandoned. There is no other widely accepted or easily defensible assumption of what goals corporate managers pursue to take its place. Given this theoretical and empirical vacuum, an argument that security is a response to differential levels of risk aversion among creditors becomes tautological: it proves the existence of security by presupposing differential levels of risk aversion, and it proves the existence of differential levels of risk aversion by showing that security exists.

With the positivist analysis in this state, two responses seem sensible. First, one can assume that corporate managers maximize share values. This response calls the risk-aversion explanation seriously into question because the corporate creditors that firms often have are then supposed to be risk-neutral, yet they sometimes take security. Second, one can treat the question what utility function corporate managers attempt to maximize as open, which implies that whether corporate creditors are risk-averse remains to be proved. With this question open, however, the risk-aversion explanation for the existence of security is not compelling.

2. Uncertainty. Security interests also could increase welfare if they reduced creditor uncertainty. In this connection, the assumption made in Part II-A above that little uncertainty exists seems unrealistic: a creditor calculating the risk of default must predict the ratio of its debt to existing debt at the time of default as well as the size of the then available asset pool, but these predictions are difficult to make precisely. A security interest may reduce this uncertainty because secured creditors have only to know whether assets will exist to satisfy their claims. Thus the lower interest rates that accompany secured debt may partly be a function of the greater certainty that security generates. Since the existence of secured debt seems not to increase uncertainty for a firm's other creditors, that fraction of the secured creditors' lower interest charge attributable to a reduction in uncertainty is a net gain to the firm. Firms, the explanation goes, issue secured debt to capture this gain.

This explanation, however, generates predictions that the facts seem not to confirm and fails to explain why creditors respond to uncertainty by taking security. First, the uncertainty explanation predicts that, other 
things equal, firms will issue as much secured debt as they can; for if security always generates net interest-rate reductions, firms always have an incentive to capture them. Firms, however, often seem not to issue as much secured debt as their assets would justify. This counterexample cannot be dismissed by arguing that the costs of taking security sometimes exceed the gains of a reduction in uncertainty and sometimes do not. In the absence of further evidence, such a response is tautological. It asserts only that security will exist when security is efficient-its gains in reducing uncertainty exceed its costs-and will not exist when it is inefficient.

Second, the uncertainty explanation predicts that creditors are less likely to take security in the assets of firms that will probably be reorganized rather than liquidated upon insolvency. ${ }^{42}$ When the possibility of reorganization is nonnegligible, the Bankruptcy Act may increase uncertainty by reducing the ability of creditors to calculate the expected value of security interests in the event of default. Initially, federal law automatically stays foreclosure when a bankruptcy petition is filed. ${ }^{43}$ : The stay's purpose is to allow time to explore the possibility of reorganization, with losses to the secured creditors supposedly being avoided by giving them "adequate protection"-interim cash payments or replacement liens based on the collateral's worth. ${ }^{44}$ To provide such protection, the collateral must of course be valued. The act, however, chooses no valuation standard, leaving the matter entirely at the bankruptcy court's discretion. A court that is permitted to choose between standards as disparate as forced liquidation or full going-concern value when deciding what the collateral is worth is likely to be influenced-indeed is encouraged to be influenced-by "equitable considerations," 45 such as assisting unsecured creditors and equity holders by preserving the estate's assets as well as

42 Smith and Wamer also assert that the probability of security varies inversely with the probability of reorganization, but rest this claim on the ability of bankruptcy courts to "prohibit the bondholders from taking possession of the property." Smith \& Wamer, supra note 2 , at 19 . Bankruptcy courts, however, are required to compensate bondholders for this loss, so Smith and Wamer must go on to show that the compensation will be inadequate. Bankruptcy lawyers do believe this often to be true. Moreover, Smith and Wamer do not ask whether the Bankruptcy Act's tendency to increase uncertainty also reduces the incentive of creditors to take security when their debtors are likely to be reorganized.

43 Bankruptcy Act $\S 362(a)(4)$.

44 Bankruptcy Act $\S \S 362,361$.

${ }^{45}$ The Senate explained the decision not to put valuation criteria in the statute as follows:

"Neither is it expected that the courts will construe the term value to mean, in every case, forced sale liquidation value or full going concern value. There is wide latitude between those two extremes although forced sale liquidation value will be a minimum. . . . [T] determination of which entity should be entitled to the difference between the going concern value and the liquidation value must be based on equitable considerations arising from the facts of the case."

Bankruptcy Reform Act of 1978, Senate Rep. No. 95-989, 95th Cong. 2d Sess., at 54 (1978). 
the possibility of successful reorganization. Because the bankruptcy court's discretion is so unconfined, the value of the "protection" to a secured party during the unspecified period in which foreclosure is stayed is hard to predict ex ante. If a reorganization is attempted, secured parties commonly are offered stock or debt in the new enterprise. The value of this property when security is taken is also hard to predict for two reasons. First, the debtor will never have operated in its reorganized form, and it is thus hard to assess the expected value of claims on its earnings. Second, the value of the stock or new debt offer that equity holders and unsecured creditors will make to secured parties to obtain their consent to a reorganization is likely to be influenced by (i) the debtor's actual prospects; (ii) the desire of the holders of equity and unsecured debt to give the debtor a second chance; and (iii) the ability of the secured parties to obstruct the reorganization. These factors too are quite difficult to assess when the initial credit extension is made.

Finally, creditors cannot significantly increase their ability to calculate the expected value of security in the event of default by planning ab initio to dissent from reorganization plans. Dissenters must receive cash or liens as compensation for the loss of rights under their security agreements, ${ }^{46}$ but granting such compensation also requires bankruptcy courts to value the collateral. In addition, the present value of the periodic cash payments that bankruptcy courts are authorized to make to dissenting secured parties must equal the "present value" of the security. A court cannot calculate the requisite payments without setting a discount rate, however, and bankruptcy courts have wide discretion, unconfined by statute or legislative history, in choosing the "appropriate" rate. In consequence, creditors will seldom be able to increase significantly their ability to calculate the present values of security interests, and hence the present values of their debt holdings, by planning to dissent from reorganization plans should their debtors become insolvent. ${ }^{47}$

Creditors of such firms as large concerns or common carriers, which are likely to be reorganized on default, are thus apt to have difficulty, when they take secured debt, in knowing what their security will ultimately be worth. The return from a secured loan may be as difficult to calculate ex ante as the return from an unsecured loan. Although security may be valuable to these creditors for other reasons, its existence is unlikely to generate the gains from a reduction of uncertainty on which the uncertainty explanation rests. This explanation thus predicts that security is

${ }^{46}$ Bankruptcy Act $\S \S 1129(\mathrm{~b})(\mathrm{i})$ and 1129(b)(2)(A).

${ }^{4 \pi}$ Valuation difficulties in reorganization contexts have become notorious. See Victor Brudney \& Marvin A. Chirelstein, Corporate Finance Cases and Materials 137-42, 158-163 (2nd ed. 1979). 
more likely to be taken when liquidation is the probable outcome of default. Such a prediction is best verified by a statistical study, but lacks support in the impressionistic evidence. Dealing with the "problem" of secured creditors, for example, is one of the principal subjects of reorganization law, thus implying the frequency of security in this circumstance. And the debtors sometimes are firms that creditors apparently can foresee are unlikely to be liquidated promptly on default. ${ }^{48}$

Respecting the second difficulty with the uncertainty explanation, loan covenants seem substitutes for security interests in reducing creditor uncertainty; these covenants require firms to maintain working capital above specified amounts, limit the extent to which firms can become claimholders in other businesses, restrict dividend payments, and require the maintenance of sinking funds, all of which help to ensure sufficient asset "cushions" so as to simplify significantly calculating risks of default. ${ }^{49}$ If security is taken because it leads to a reduction in uncertainty, this must be because it sometimes performs the function of reducing uncertainty more cheaply than do loan covenants. No explanations of when and why security is cheaper than loan covenants exist, however. In sum, because of apparent counterexamples and the failure to explain why security is taken, the uncertainty theory is also unsatisfactory given the evidence that now exists.

3. Heterogeneous Expectations Respecting Default. The argument in Part II-A that security fails to generate net gains for a firm presupposed that the firm's creditors assigned equal probabilities to default. If this assumption is relaxed, security may increase welfare. To see why, recall that the premium which creditors charge for bearing the risk of default was represented by the equation $X=p(-P+b A)$. The example above assumed that the debtor had $\$ 100$ in available assets and wished to borrow $\$ 110$ from creditor $C_{1}$ and $\$ 90$ from $C_{2}$; each creditor assigned a .01 probability to default. Suppose instead that $C_{1}$ chose a .02 default probability. Then, using the equation, if both creditors are unsecured, the premium they will charge because of the risk of default is $\$ 1.55$, but if $C_{1}$ is secured the total premium drops to $\$ 1.10$. And to generalize, it is always efficient for the firm to secure the creditor that assigns the highest probability to default.

${ }^{48}$ For example, bondholders in common carrier bankruptcies are often secured. See, e.g., New Haven Inclusion Cases, 399 U.S. 392 (1970). See also In re Yale Express, 384 F.2d 990 (2d cir. 1967).

49 A thorough description of loan covenants is contained in Smith \& Wamer, supra note 2. The existence of loan covenants as substitutes for security interests also cuts against the validity of the monitoring-cost explanation. See text at notes $27-31$ supra. 
This explanation initially seems plausible because a firm's creditors could assign different probabilities to the likelihood of default. The probability that a firm will default is a function, inter alia, of the length and size of loans and not all of a firm's debt is likely to be of the same length and size. The heterogeneous-expectations explanation, however, is difficult to confirm with the sparse data that now exist. The explanation predicts that long-term or large debt will be secured more frequently than short-term or small debt, but the issue is not length or size simpliciter but whether length or size differs enough to generate different default probabilities on the part of creditors. Thus the explanation is not necessarily disconfirmed by the practice of firms, whose financing is primarily short-term, often to issue some secured debt. For particular debtors, a six-month loan may be long-term if the question is default probability. Nor is the explanation necessarily disconfirmed by the practice of some firms never to sell secured debt although they obtain credit for different periods or in different magnitudes. Such firms may nevertheless pose similar probabilities of default because of their earning capacities or other factors. The heterogeneous-expectations explanation is thus similar to the uncertainty explanation. It is internally coherent but is weakened by apparent counterexamples that themselves could conceivably be dissolved by adequate empirical investigation. ${ }^{50}$

${ }^{50}$ Lawyers sometimes argue that security is desirable because it enables firms in financial difficulty to borrow rather than go bankrupt. This argument is more a justification of some forms of security than an explanation of the existence of security itself, because many firms issue secured debt before they are in trouble. Further, when a firm is having difficulties its assets often seem to be liened: thus this bankruptcy-avoidance argument actually purports to justify "super priorities," in which later secured lenders obtain priority over earlier secured lenders in assets that are subject to the earlier secured lenders' security interests. The code creates such priorities, and the Bankruptcy Act ratifies them. See U.C.C. $\S \S 9-301$ and 9-312 (purchase money security interests) and § 9-308 (purchasers of chattel paper). The code's rules would be justifiable on efficiency grounds if the earlier secured creditors would voluntarily have subordinated themselves to the later secured creditors; in this circumstance, the code's creation of super priorities would actually represent the drafting of subordination agreements for the parties, and would thus save transaction costs. No good reasons are apparent, however, for why early secured creditors would commonly agree to subordinate their liens to later secured creditors when their common debtors are in difficulty. Another efficiency justification for the code and Bankruptcy Act is possible, however. Suppose that a debtor's going-concem value would exceed its liquidation value if the debtor could get cash with which to continue, but that no creditor would lend unless it received the highest priority. In this case, granting priority would be optimal for the group of earlier creditors, but agreeing to the priority might not be optimal for a particular early secured creditor; such a creditor could perhaps do better by foreclosing against a shaky debtor than by taking its chances in a lower priority position than it had previously enjoyed. The code's granting of a super-priority position to the later creditor in return for lending new funds may therefore be efficient. It would permit the debtor to continue and thus lead to the optimal outcome for the creditors as a group.

This efficiency story is promising but has difficulties. First, it fails to explain why the parties generally issue security but rather justifies the law's protection of security interests 


\section{F. Summary}

Efficiency explanations for the existence of secured debt suffer from one or more of three difficulties. First, they seem to predict wrongly the absence or presence of security (monitoring costs, staggering debt, uncertainty, heterogeneous expectations). Second, they fail to explain why creditors and firms use security rather than other devices (signaling, risk aversion, uncertainty). Third, they fail to show that the social gains from secured debt exceed its social costs (signaling). Some of these explanations seem plausible in particular circumstances, suggesting that if they were combined a valid efficiency explanation of secured debt could be developed. Combining explanations, however, is an unsatisfactory response to the difficulties that each explanation faces. These explanations actually are theories. If a theory explains one set of circumstances but fails to account for a second important set of circumstances, and another theory accounts for the second set but fails to account for the first, it is wrong to say that the world is well understood because our theories account for all relevant events. The world is poorly understood because two weak theories exist. To be sure, a metatheory combining the best elements of both may resolve all difficulties, but no such metatheory of security exists. In consequence, the efficiency justification for the current bankruptcy priority list is unsatisfactory in its present form. Before exploring the normative implications of this difficulty, we shall consider

under particular circumstances. Second, the story presupposes that later creditors would lend with security but would not make loans at interest rates that adequately compensated them for the risks they would take if they lent unsecured. The assumption apparently needs justification. Third, this efficiency story fails to justify present state law because the code grants super priorities to secured debt issued by debtors in complete financial health. A purchase money secured party, for example, takes priority over an after-acquired property financer regardless of the debtor's financial status. The Bankruptcy Act, however, allows a bankruptcy trustee who is operating the debtor's business during bankruptcy proceedings to sell debt senior to existing debt only if this is essential to the debtor's continuance (and if the early secured parties receive "adequate protection"). \& 364(d). Theories focusing on the consequences of dissolving the debtor thus may have promise for ultimately explaining and justifying aspects of bankruptcy liquidation law.

A final possible efficiency explanation of secured debt is that security reduces collection costs. A secured creditor need not sue a debt to judgment and execute on its debtor's assets, nor need it participate in a bankruptcy liquidation; rather, the creditor can simply take the property subject to its lien. See U.C.C. § 9-503. This explanation suffers from the same difficulties as some of those described above. In particular, collection costs apparently vary inversely with the size of the asset pool; that is, the more assets there are the easier it is to collect a debt. Thus when a creditor removes assets from the common pool, the collection costs of unsecured creditors rise. The issue then is whether the decline in the secured creditor's expected collection costs exceeds the rise in the unsecured creditors' expected collection costs. The answer to this question is not obvious. Moreover, secured parties often cannot foreclose when their debtors default because the Bankruptcy Act continues the collateral in the debtor's possession to preserve the possibility of reorganization. See text at notes 43-47 supra. 
distributional explanations for the existence of security, to analyze more fully the motivations of firms in granting it.

\section{Distributional Explanations}

\section{A. The "Offensive" Distributional Explanation}

Distributional explanations for the existence of secured debt are of two related kinds - the "offensive" and the "defensive." 51 The former relaxes the assumption made in Part II-A that a firm's unsecured creditors are aware of security and react to its issuance by raising their interest rates. Suppose that some of these creditors fail to do this. Firms would then have an incentive to issue secured debt because they would benefit from the lower interest rates secured creditors would charge but not be harmed by higher interest rates charged elsewhere. In this circumstance, secured debt redistributes wealth from uninformed creditors (who fail to react to security) to firms. ${ }^{52}$ Firms would then be anxious to make secured loans, so demand for these loans would increase; thus secured creditors-primarily banks and finance companies-would share some of the gains made at the expense of the uninformed creditors.

This distributional explanation predicts that firms will issue secured debt only when a substantial number of their creditors are uninformed. The prediction has some empirical support. Consider retailers in consumer markets. A retailer's creditors include not only its financers and sellers but also its customers and employees. A customer who buys from a retailer has a potential warranty claim. Further, hard goods, such as appliances or cars, often are bought with service contracts or under the standard repair or replacement warranty. Customers who have made partial or full payment would be entitled to restitution if the goods are defective. Retailers are debtors respecting consumer-warranty claims; that is, customers have potential claims against retailers for money or services, and the retailers have a corollary potential liability. If assets are withdrawn from the pool otherwise available to satisfy the warranty claims of customers and devoted to the claims of different creditors, the purchase risks of the customers are increased; their claims against firms will be more difficult to satisfy. Purchases from "secured firms" are, consequently, less attractive than purchases from unsecured firms, so the secured firms should command lower prices. These lower prices are the

${ }^{51}$ Both explanations are described in James H. Scott, Bankruptcy. Secured Debt, and Optimal Capital Structure: Reply, 34 J. Finance 253 (1979); and James H. Scott, Bankruptcy, Secured Debt, and Optimal Capital Structure, 32 J. Finance 1 (1977).

52 The text supposes an "uninformed creditor" to be ignorant of the existence of security or not sophisticated enough to respond appropriately to security if he or she knows of it. 
product-market equivalent of the higher interest rates that unsecured creditors in financial markets charge to a firm that issues secured debt. But if retail customers are unaware of the existence of security, their demand for the goods of secured firms will be unaffected by it. These customers consequently will pay higher prices than they should pay, as measured by their own (informed) preferences. The excess will be shared
by retailers and their financers.

Employees are creditors for their wages and should receive higher wages, other things equal, from secured than from unsecured firms because security makes the former firms more risky to deal with. Retail employees, however, are less likely to be organized than manufacturing employees and more likely to be employed on a casual or seasonal basis. Retail employees may therefore have relatively less power and knowledge than manufacturing employees to demand higher wages from secured firms, with the result that these firms (and their financers) may capture some of the wealth of the employees.

The offensive distributional explanation seems correctly to predict that firms will issue secured debt when a substantial number of their creditors are uninformed. ${ }^{54}$ It apparently predicts wrongly the absence of security, however, in cases when most of a firm's creditors would be aware of security and could react to its existence. As Part II-B showed, when creditors are informed and capable, security generates no reductions in net interest rates for the firm. Thus the offensive distributional explanation predicts that those industrial firms whose sellers, buyers, and financers all seem sophisticated will rarely secure the debt they sell. In practice, however, these firms often issue some secured debt. This explanation therefore is also unconvincing.

\section{B. The "Defensive" Distributional Explanation}

The defensive distributional explanation assumes that creditors are informed and competent. Suppose that a creditor is asked to lend unsecured to a firm that has issued no secured debt. Will it charge an interest rate

\footnotetext{
${ }^{53}$ Customer claims arise not only from warranties but also from the purchase of goods on "layaway" or the purchase of gift certificates or money orders. The new Bankruptcy Act accords fifth priority to

". . . individuals, to the extent of $\$ 900$ for each such individual, arising from the deposit ... of money in connection with the purchase, lease or rental of property, or the purchase of services, for the personal, family or household use of such individuals, that were not delivered or provided."

$\S 507(a)(5)$. Fifth-priority claimants are unlikely to do well. Less frequently, consumers can have tort claims or claims for late or nondelivery.

54 The offensive distributional explanation can coexist with explanations that claim secured debt to be efficient in the Kaldor-Hicks sense. See note 7 supra.
} 
reflecting that all of the firm's assets are available to satisfy creditor claims? It may not because, if this relatively low rate is charged, the firm has an incentive to issue secured debt after the initial loan is made. By so doing, it would obtain the advantage of the lower rate secured debt commands without the disadvantage of the higher rate unsecured creditors would charge in response. Creditors, however, anticipating the later issuance of secured debt, will charge the interest rate for unsecured debt that would be charged if the firm were already secured. ${ }^{55}$ But if this is done, the firm must promptly issue secured debt: only in this way can it offset the high interest rates required by its creditors' anticipation that such debt will later be issued. Further, the two distributional explanations can be combined: firms issue secured debt to defend themselves against informed creditors who expect it and to exploit uninformed creditors who are ignorant of it.

The "defensive" distributional explanation suffers from familiar difficulties. It predicts that all firms initially will borrow secured, and will secure as much debt as they can. This is because if a firm's first creditor will charge an interest rate that reflects later security, the firm should secure the first creditor (and all others so long as it has free assets). In this way, it can receive the benefit of secured debt's lower interest rate as soon as possible. Nothing is gained and something lost by securing the seventh rather than the first creditor, when some creditors will have to be secured in any event. Yet many firms fail to borrow according to this pattern.

Another difficulty with the explanation is that firms to some extent can prevent early unsecured creditors from charging interest rates that reflect anticipated security by using loan covenants. Common covenants prohibit firms from issuing later debt with a higher priority than early debt. These prohibitions sometimes specifically refer to purchase money and real estate mortgages. ${ }^{56}$ In addition, covenants sometimes expressly protect early creditors against later issuance of security by providing that the early creditors "must have their priority upgraded and be given an equal claim on the collateral with the secured debtholders." ${ }_{57}$ If security per-

55 If creditors suppose the probability that a firm will issue security after a loan is made to be less than one, the firm can exploit these creditors by issuing security. This is because a probability figure less than one implies an interest rate that does not fully reflect the existence of security. In this case, the firm can make gains by later issuing it. Early creditors thus have an incentive to assume that later secured debt will be issued with a probability of one, as the text supposes. Creditors, however, do have incentives to set realistic probability figures. If those figures are less than one, the defensive distributional explanation nevertheless holds.

${ }^{56}$ Smith \& Wamer, supra note 2, at 32-34.

${ }^{57} I d$. at 32. 
forms the function of forestalling initially high interest rates, it must be because in some cases it does so more cheaply than loan covenants would. Explanations of when and how this would occur are lacking.

If valid, the defensive distributional explanation is nevertheless normatively troubling. Should security generate no reductions in net interest rates but be used to prevent creditors from capturing the wealth of firms, the giving of security represents a deadweight efficiency loss. No new wealth is created by the issuance of security, yet since resources are devoted to creating it, someone is made worse off by its existence.

\section{Normative Implications and a Research Agenda}

Parts II and III of this paper argue that no convincing explanation for the issuance of short-term secured debt exists; it is not known with assurance whether security is efficient, as some explanations of its existence assert, or inefficient, as the signaling and distributional explanations suggest is possible. With the record in this state, it may seem appropriate for a decision maker to pursue whatever normative views respecting bankruptcy liquidations he happens to hold. In particular, since Congress has already selected a set of creditors for special treatment, the priority of these creditors perhaps should be raised above that of secured parties, on the ground that a good case for subordinating them has yet to be made. Such an action, or others actuated by similar motives, would now be premature because satisfactory normative reasons for altering current law are also hard to find. In consequence, this part first explores the implications of law reform that follow from a rejection of the efficiency justification for the current bankruptcy priority list. It next illustrates the difficulties that make significant law reform unwise at present and concludes with a brief summary of the important unresolved positive and normative issues respecting bankruptcy liquidations.

\section{A. Possible Reforms}

Suppose that the assumption of creditor knowledge and ability to react to security is partially false, that some creditors are disadvantaged by firm failures they can neither foresee nor avoid. Two reforms are then implied: to prohibit security or make it much more difficult to take, or to elevate the priority status in bankruptcy liquidations of particular creditor groups. The former reform is unwise. Secured debt has not been shown to be inefficient; the signaling and distributional explanations indicate only that inefficiency is conceivable. Thus significantly reducing the opportunity to take security seems precipitate. Further, creditors and firms are likely to want a good deal of security even at higher cost levels, as they did before 
the code. Reducing the costs to many parties of doing what they would do anyway thus will produce some gains. Finally, any harm that secured debt generates will fall heaviest on particular unsecured creditors. The freedom of firms and secured creditors is maximized if these commercial parties are unregulated but those disadvantaged by security are helped directly. All these reasons suggest that the cost-reducing innovations of article 9 should be preserved even if the assumption of creditor knowledge is sometimes false.

The appropriate response to creditor ignorance is to elevate the priority status of those creditors thought deserving of help. At present, secured parties are paid in full, to the extent of their security interests, before any other creditors are paid. Any effort at law reform should alter this priority list: consumers, employees, small-trade creditors, tort claimants, or any others whom Congress wants to favor should be paid first, either in full or up to statutorily created levels. Such a reform would increase the costs of secured debt. Secured creditors would be able to realize less on default, and greater uncertainty would attend the use of security since secured creditors would have difficulty predicting the extent to which they may later be subordinated. Nevertheless, revising priorities is preferable to increasing the costs of secured debt in other ways. Priority revision helps directly those thought deserving of help and gives firms and secured creditors more freedom in arranging their affairs.

\section{B. Issues to Be Resolved before Revising the Priority List}

That distributional or other normative objectives should be pursued more vigorously in bankruptcy contexts fails to follow from a showing that security conceivably is inefficient. An affirmative law reform case must be made because pursuit of any such case is expensive. The case for revising priorities seems strongest when particular creditors are unaware of or cannot react to security. In this circumstance, firms and sophisticated creditors use secured debt with the possible intention and certain effect of redistributing wealth to themselves and from creditors who would prevent these redistributions were they informed. Notions of corrective justice imply a remedy for the disadvantaged creditors in this circumstance. A theory of corrective justice provides that a plaintiff cannot prevail against a defendant unless the defendant has wrongfully harmed some interest of the plaintiff. Such a theory must therefore identify which interests "belong to" or are "owned" by the plaintiff as well as what actions "wrongfully" harm these interests. Corrective justice theorists give content to the concepts of interests and wrongs by reference 
both to moral theories and to widely shared moral sentiments. ${ }^{58}$ In issues of bankruptcy priority, most moral theories as well as commonly shared moral notions accord persons or business entities protected interests in property. When wealth is redistributed from inept or uninformed creditors, their interests prima facie have been invaded. Further, the moral sentiments of ordinary persons might consider the invasion to be wrongful, for it reflects the disadvantaging of the weak by the strong. Thus corrective justice could require unsophisticated or ignorant creditors to have a remedy against the firms and secured creditors that harmed them.

The case for corrective justice does not seem compelling because ordinary persons probably would not regard security as wrongful in the same sense that fraud or theft is, particularly since secured parties and firms sometimes may fail to realize that they are inflicting harm on other creditors. Also, the harm done often seems relatively slight. A decision maker deciding whether to recognize a right on corrective justice grounds is entitled to consider the consequences that recognition would entail. If security were shown to be efficient in the Kaldor-Hicks sense, ${ }^{59}$ this efficiency would count against a corrective justice right to a revised priority list, because pursuit of this right would raise the costs and thus reduce the gains from security. But a persuasive showing of efficiency has not been made and in its absence a decision maker could justifiably pursue the plausible corrective justice case for revising bankruptcy priorities. ${ }^{60}$

${ }^{58}$ See, e.g., John Borgo, Causal Paradigms in Tort Law, 8 J. Legal Stud. 419 (1979); Richard A. Epstein. Intentional Harms, 4 J. Legal Stud. 391 (1975): Richard A. Epstein, A Theory of Strict Liability, 2 J. Legal Stud. 151 (1973): George P. Fletcher, Faimess and Utility in Tort Theory, 85 Harv. L. Rev. 537 (1972). For a critical discussion of corrective justice theories, see Izhak Englard. The System Builders: A Critical Appraisal of Modern American Tort Theory. 9 J. Legal Stud. 27, $57-68$ (1980). See also Richard A. Posner, Epstein`s Tort Theory: A Critique. 8 J. Legal Stud. 457 (1979).

${ }^{59}$ Security could be efficient in the Kaldor-Hicks sense if it generated cost reductions for firms and secured creditors that exceeded the (uncompensated) cost increases of the unsecured creditors. See note 7 supra. In recent years, serious questions have been raised concerning whether it is normatively desirable or sometimes even technically feasible for decision makers to pursue the Kaldor-Hicks efficiency goal, as that goal is traditionally conceived. Even if security were shown to be efficient in the restricted world of economic models, the extent to which this efficiency should count against adoption of the corrective justice case for bankruptcy priority reform would remain an open question. But since no plausible theoretical efficiency explanations of security now exist, analysis of the efficiency goal itself is beyond the scope of this paper.

${ }^{60}$ Professor Kronman has recently argued that it sometimes is appropriate to pursue distributional concems in contexts where all parties bargain with each other. Anthony T. Kronman, Contract Law and Distributive Justice, 89 Yale L. J. 472 (1980). The area of secured debt and bankruptcy priorities may constitute such a context. In addition to the difficulties about to be discussed respecting such a pursuit, however, it should be added that 
Before acting on this case, however, the factual accuracy of its premises must be shown, not asserted. This is a difficult task. Plausibly establishing the incompetence of contracting parties, such as the employees and consumers at issue here, is hard to do. ${ }^{61}$ The incompetence of employees is especially problematic when, as often happens, the employees are organized in unions. Further, it is not enough to show that some of these parties are uninformed, because markets can work well in the face of substantial numbers of uninformed persons. The informed employees and consumers in some cases may police the market sufficiently to ensure that wages and prices accurately reflect the existence of security ${ }^{62}$ Thus the seemingly plausible corrective justice case for revising bankruptcy priorities is in fact premature because the circumstances in which it would apply have yet to be established.

When this case is inapplicable, a persuasive normative argument for revising bankruptcy priorities seems hard to find. Consider "small-trade" creditors, who supposedly are among the class disadvantaged by current law. These creditors must now be assumed able to anticipate bankruptcy and learn of security, for such creditors would otherwise be injured by security in the way the corrective justice case supposes. But if these assumptions were true, the small-trade creditors would be compensated for bearing the risk of a low priority status in bankruptcy because the cost of this risk would be an element of the market price that their buyers must pay. The trade creditors would seem to need no help from the state in this circumstance. Further, if bankruptcy priorities were revised, the costs to banks and finance companies of extending credit would be raised, with the result that these entities might make fewer loans. This outcome would disadvantage the employees and shareholders of the banks and finance companies. On the information that now exists, it is difficult to say that these persons are less "deserving" than the persons who own or work for the small-trade creditors. No normative ground for revising bankruptcy priorities thus seems apparent except the corrective justice case.

any discussion of distributional issues in bankruptcy is incomplete without a consideration of the government's tax priority. See Bankruptcy Act $\S 507(a)(6)$. This priority seriously disadvantages general creditors. Also, the Pension Benefit Guarantee Corporation, a Federal agency, has a lien superior to the claim of unsecured creditors on the assets of a firm that fails to fund fully certain pension plans. See ERISA, § 4068, 29 U.S.C. $§ 1368$ (1975). Given the large number of pension plans now in existence, this lien could also harm unsecured credit extenders. Discussion of the appropriateness of these government priorities is beyond the scope of this paper.

${ }^{61}$ See Alan Schwartz, A Reexamination of Nonsubstantive Unconscionability, $63 \mathrm{Va}$. L. Rev. 1053 (1977).

${ }^{62}$ See Schwartz \& Wilde, supra note 37. 


\section{Issues That Deserve Study}

The normative desirability of any bankruptcy priority list cannot be convincingly established on the basis of current knowledge. The conventional view that article 9 of the Uniform Commercial Code and the Bankruptcy Act strike a desirable balance between the interests of secured and unsecured creditors thus is seriously deficient. Before accepting it or any other conclusion, research should be done on the following issues: ( $i$ ) Can explanations of the existence of secured debt be developed that are testable and account for much of the observed data? (ii) The observed data is largely the product of casual empiricism. Would rigorous empirical work confirm theories that now seem questionable or indicate possibilities of new theories? (iii) When do the factual premises of the corrective justice case hold? (iv) Apart from this case, can a coherent normative argument for revising the bankruptcy priority list be made?

\section{Conclusion}

Present bankruptcy law provides that secured parties are to be paid first and in full before any other creditors of an insolvent debtor are paid at all. The principal justification for this priority list is that short-term secured debt is efficient and thus its purchase should be as convenient as possible. This justification has not been proved; no plausible showing that secured debt actually increases welfare exists. Further, firms in some circumstances may issue such debt to redistribute wealth to themselves from just those persons to whom standard distributional rationales would accord special treatment. If, in light of these conclusions, different normative concerns should be pursued in bankruptcy liquidations, the appropriate method for doing so is to elevate the priority status of those thought to require more favorable treatment. But these conclusions do not themselves support such a course. That the efficiency justification for present law is problematic means only that other concerns should become relevant, not paramount. Attention should now focus on whether the efficiency justification can be made persuasive and whether attractive normative cases for particular bankruptcy priority lists can be made out. Inquiries of this sort, it may be remarked, probably are appropriate in related contexts as well because positivist explanations of several other legally relevant financial practices also seem relatively undeveloped. 